\title{
PENGARUH NET PROFIT MARGIN, EARNING PER SHARE, CURRENT ASSET DAN PRICE TO BOOK VALUE TERHADAP RETURN SAHAM PADA PERUSAHAAN MANUFAKTUR SUB SEKTOR KIMIA YANG TERDAFTAR DI BURSA EFEK INDONESIA (BEI) PERIODE 2014-2018
}

\author{
Ramzijah $^{(1)}$, Nazariah $^{(2)}$, Fandi Maldini $^{(3)}$ \\ ${ }^{1,2,3}$ Program Studi Akuntansi Fakultas Ekonomi Universitas Jabal Ghafur \\ Email : ramzijah@unigha.ac.id
}

\begin{abstract}
ABSTRAK
Tujuan penelitian ini ingin menguji dan menganalisis variabel independen Net Profit Margin (NPM), Earning per share (EPS), Current Asset (CA) dan Price to Book Value (PBV) terhadap return saham. Populasi dalam penelitian ini adalah seluruh perusahaan manufaktur sub sektor kimia yang terdaftar di bursa efek indonesia (BEI) periode 2014-2018. Teknik yang digunakan untuk pengambilan sampel adalah purpusive sampling. Sampel dalam penelitian ini adalah perusahaan manufaktur sub sektor kimia periode 2014-2018 dan yang menerbitkan laporan keuangan setiap tahunnya. Berdasarkan kriteria jumlah sampel yang diambil hanya 9 perusahaan. Analisis yang digunakan dalam penelitian.Hasilnya adalah variabel independen NPM dan CA berpengaruh secara positif dan signifikan terhadap return saham sementara PBV berpengaruh secara negatif dan signifikan terhadap return saham, sedangkan pada EPS tidak berpengaruh secara signifikan terhadap return saham pada perusahaan manufaktur sub sektor kimia yang terdaftar di bursa efek indonesia (BEI) periode 2014-2018. Hasil penelitian ini diketahui nilai koefisien determinasi sebesar 0,669 atau 66,9\% yang menunjukkan bahwa variabel dependen yang digunakan dapat dijelaskan oleh variabel net profit margin (NPM), Earning per share (EPS), Current Asset (CA) dan Price to Book Value (PBV) sedangkan sisanya sebesar 33,1\% dijelaskan oleh faktor-faktor yang lain yang di anggap tetap yang tidak dimasukkan ke dalam penelitian ini.
\end{abstract}

Kata Kunci: Net Profit Margin (NPM), Earning per share (EPS), Current Asset (CA), Price to Book Value (PBV) dan return saham.

\section{PENDAHULUAN}

\subsection{Latar Belakang Masalah \\ Dunia yang semakin canggih} teknologi membuat persaingan industri manufaktur meningkatkan kinerja agar tujuannya dapat tercapai sesuai dengan yang telah direncanakan dahulu. Salah satu tujuan perusahaan adalah untuk memaksimumkan kemakmuran para pemegang saham..

Di Indonesia perkembangan industri dasar dan kimia sangat pesat, hal ini dapat dilihat dari perkembangan industri dasar dan kimia yang terdaftar di BEI dari tahun ke tahun semakin bertambah, maka tidak menutup kemungkinan perusahaan ini sangat dibutuhkan 
oleh masyarakat dan prospeknya akan menguntungkan di masa yang akan datang.

Pasar modal merupakan salah satu sarana yang efektif untuk mempercepat akumulasi dana bagi pembiayaan pembangunan melalui mekanisme pengumpulan dana dari masyarakat dan menyalurkan dana tersebut ke sektor-sektor produktif. Dengan berkembangnya pasar modal, maka alternatif investasi bagi para pemodal kini tidak lagi terbatas pada aktiva riil dan simpanan pada sistem perbankan melainkan dapat menanamkan dananya di pasar modal, baik dalam bentuk saham, obligasi, maupun sekuritas (aktiva finansial) lainnya.

Oleh karena itu, biasanya return yang diharapkan pada investasi saham relatif lebih besar dibandingkan tingkat bunga simpanan pada bank-bank. Investor dalam menanamkan dananya membutuhkan berbagai informasi yang berguna untuk memprediksi hasil investasi dalam pasar modal.

Para investor menggunakan berbagai cara memperoleh return yang diharapkan, baik melalui analisis sendiri terhadap perilaku perdagangan saham, maupun dengan memanfaatkan sarana yang diberikan oleh para analisis pasar modal, seperti broker dan manajer investasi. Pola perilaku perdagangan saham di pasar modal dapat memberikan kontribusi bagi pola perilaku harga saham di pasar modal tersebut. Pola perilaku harga saham akan menentukan pola return yang diterima dari saham tersebut.

Laporan keuangan akan melaporkan posisi perusahaan pada satu titik waktu tertentu maupun operasinya selama suatu periode masa lalu. Dari sudut pandang seorang investor, meramalkan masa depan adalah hakikat dari analisis laporan keuangan sedangkan dari sudut pandang manajemen, analisis laporan keuangan akan bermanfaat baik untuk membantu mengantisipasi kondisi- kondisi di masa depan, maupun yang lebih penting lagi, sebagai titik awal untuk melakukan perencanaan langkah-langkah yang meningkatkan kinerja perusahaan di masa mendatang.

Melalui rasio-rasio keuangan kita bisa membuat perbandingan suatu perusahaan dari waktu ke waktu untuk mengamati kecenderungan (trend) yang sedang terjadi, dan juga membandingkan rasio keuangan sebuah perusahaan dengan perusahaan lain yang masih bergerak dalam industri yang relatif sama periode tertentu. Rasio-rasio yang digunakan di dalam penelitian ini meliputi rasio profitabilitas, rasio nilai pasar dan juga dilakukan melalui current asset (aset lancar) terhadap return saham pada perusahan manufaktur sub sektor kimia yang terdaftar di Bursa Efek Indonesia.

Return saham merupakan hasil yang diperoleh dari kegiatan investasi. Return dibedakan menjadi dua, yaitu return realisasi (realized return) merupakan return yang telah terjadi dan return ekspektasi (expected return) merupakan return yang diharapkan akan diperoleh oleh investor dimasa mendatang.

\begin{tabular}{lrr}
\multicolumn{2}{c}{ Rasio } & \multicolumn{2}{c}{ profitabilitas } \\
merupakan & rasio & yang melihat \\
kemampuan & \multicolumn{2}{c}{ perusahaan } \\
menghasilkan & keuntungan pada
\end{tabular}


tingkat penjualan, aset dan modal saham yang tertentu. Ada tiga rasio yang sering dibicarakan yaitu: net profit margin (NPM), gross profit margin (GPM), return on asset (ROA) dan return on equity (ROE), dalam penelitian ini digunakan $\mathrm{Net}$ profit margin (NPM) yaitu rasio yang menghitung sejauh mana kemampuan perusahaan menghasilkan laba bersih pada tingkat penjualan tertentu. Rasio ini bisa dilihat secara langsung pada analisis common size untuk laporan laba rugi ( baris paling akhir). Rasio ini bisa diinterprestasikan juga sebagai kemampuan perusahaan menekan biaya - biaya di perusahaan pada periode tertentu.

Yang kedua adalah rasio nilai pasar yaitu rasio yang mengambarkan kondisi yang terjadi di pasar. Rasio ini mampu memberikan pemahaman bagi pihak manajemen perusahaan terhadap kondisi penerapan yang akan dilaksanakan dan dampaknya pada masa yang akan datang. Analisa yang digunakan dalam rasio ini adalah earning per share dan price to book value.

Current Asset merupakan merupakan aset yang memiliki tingkat perputaran yang tinggi dan paling cepat bisa di jadikan uang tunai, dengan penepatan periode waktu biasanya 1 (satu) tahun. Oleh karena itu bagi suatu manajer perusahaan paling penting memahami dan menempatkan analisa pemilihan keputusan pembelian dan kepemilikan aktiva berdasarkan konsep aktiva likuid. Aktiva likuid (liquid asset) adalah aktiva yang dapat diubah menjadi kas dengan cepat tanpa harus menurunkan harga aktiva tersebut.

\subsection{Rumusan Masalah}

Berdasarkan latar belakang diatas, maka rumusan masalahnya, adalah, apakah Net profit margin, earning per share, current asset, price to book value secara partial dan simultan berpengaruh terhadap return saham pada perusahaan manufaktur sub sektor kimia yang terdaftar di BEI periode 2014-2018?

\subsection{Tujuan Penelitian}

Adapun tujuan peneliatian adalah Untuk mengerahui Net profit margin, earning per share, current asset, price to book value secara partial dan simultan berpengaruh terhadap return saham pada perusahaan manufaktur sub sektor kimia yang terdaftar di BEI periode 2014-2018?

\subsection{Manfaat Penelitian}

Adapun manfaat yang diharapkan adalah sebagai berikut :

1. Manfaat teoritis yaitu bagi civitas akademis adalah sebagai sumber bacaan atau referensi yang dapat memberikan informasi teoritis dan empiris pada pihak-pihak yang akan melakukan penelitian lebih lanjut mengenai permasalahan ini, serta dapat menambah sumber pustaka yang telah ada.

2. Manfaat praktis untuk Manajemen

Perusahaan sebagai masukan atau dasar untuk meningkatkan kinerja perusahaan yang dilihat dari rasio keuangan sehingga menunjukkan prospek yang baik untuk perusahaan dimasa 
yang akan datang sehingga menarik perhatian para investor, sementara bagi Investor sebagai salah satu referensi dalam pengambilan keputusan penanaman modal yang akan dilakukan pada perusahaan manufaktur sub sektor kimia.

\section{HASIL PENELITIAN DAN PEMBAHASAN}

\subsection{Data Penelitian}

Analisis data dimulai dengan mengolah data dengan menggunakan microsoft excel, selanjutnya dilakukan pengujian asumsi klasik dan pengujian menggunakan analisis linier berganda. Pengujian asumsi klasik dan analisis linier berganda digunakan dengan menggunakan software SPSS versi 20. Prosedur dimulai dengan memasukkan variabel-variabel penelitian ke program SPSS tersebut dan menghasilkan output sesuai dengan metode analisis data yang telah ditentukan

\subsection{Statistik Deskriptif Sampel Penelitian}

Statistik deskriptif digunakan menunjukkan jumlah data $(\mathrm{N})$ yang digunakan dalam penelitian ini serta dapat menunjukkan hasil nilai maksimum, nilai minimum, nilai rata-rata (mean) serta standar deviasi dari masing-masing variabel. Dalam penelitian ini pengaruh Net Profit Margin (NPM), Earning per share (EPS), Current Asset (CA) dan Price to Book Value (PBV) terhadap return saham pada perusahaan manufaktur sub sektor kimia yang terdaftar di bursa efek indonesia (BEI) periode 2014-2018
Tabel 4.1

Descriptive Statistics Variabel penelitian

\begin{tabular}{|l|r|r|r|r|r|}
\hline \multicolumn{7}{|c|}{ Descriptive Statistics } \\
\hline NPM & N & Minimum & Maximum & Mean & $\begin{array}{c}\text { Std. } \\
\text { Deviation }\end{array}$ \\
EPS & 45 & $-574,23$ & 15,95 & $-15,3033$ & 93,78561 \\
CA & 45 & $-231,27$ & 1226,36 & 108,3384 & 267,41599 \\
PBV & 45 & 25517 & 28464154 & 3670711,5 & 6538363,467 \\
RS & 45 &,- 503 & 11,187 &, 93671 & 1,844391 \\
Valid N (listwise) & 45 &,- 700 & 10,227 &, 48776 & 1,711635 \\
\hline
\end{tabular}

Sumber : Data diolah SPSS versi 20, 2020

Berdasarkan Tabel 4.1 dapat dilihat bahwa net profit margin (NPM) menunjukkan bahwa perusahaan manufaktur sub sektor kimia memiliki nilai minimum sebesar $-574,23 \%$ nilai tersebut dialami oleh perusahaan Eterindo Wahanatama Tbk pada tahun 2018. Sedangkan nilai maksimumnya sebesar $15,95 \%$ dialami oleh perusahaan Ekadharma International Tbk pada tahun 2016, dan standar deviasi nya adalah $93,78561 \%$.

Earning per share (EPS) menunjukkan bahwa perusahaan manufaktur sub sektor kimia memiliki nilai minimum sebesar Rp.231,27 nilai tersebut dialami oleh perusahaan Eterindo Wahanatama Tbk pada tahun 2015. Sedangkan nilai maksimumnya sebesar Rp.1.226,36 dialami oleh perusahaan Chandra Asri Petrochemical Tbk pada tahun 2016, dan standar deviasi nya adalah Rp.267,41599.

Current Asset (CA) menunjukkan bahwa perusahaan manufaktur sub sektor kimia memiliki nilai minimum sebesar Rp.25.517 nilai tersebut dialami oleh perusahaan Eterindo Wahanatama Tbkpada tahun 2018. Sedangkan nilai maksimumnya sebesar Rp.28.464.154 dialami oleh perusahaan Barito Pacific Tbk pada 
Jurnal Sains Riset (JSR)

p-ISSN 2088-0952, e-ISSN 2714-531X

http://journal.unigha.ac.id/index.php/JSR

DOI. $10.47647 /$ jsr.v10i12

tahun 2018, dan standar deviasi nya adalah Rp.6.538.363,467.

Price to Book Value (PBV) menunjukkan bahwa perusahaan manufaktur sub sektor kimia memiliki nilai minimum sebesar Rp.0,503 , nilai tersebut dialami oleh perusahaan Eterindo Wahanatama Tbkpada tahun 2017. Sedangkan nilai maksimumnya sebesar Rp.11,187, dialami oleh perusahaan Eterindo Wahanatama Tbk pada tahun 2016, dan standar deviasi nya adalah Rp.1,832116.

Return saham (RS) dari perusahaan manufaktur sub sektor kimia menunjukkan nilai minimumnya adalah Rp.-0,700, nilai tersebut dialami oleh perusahaan Eterindo Wahanatama Tbk pada tahun 2015. Dan nilai maksimumnya adalah Rp.10.227, nilai tersebut dialami oleh perusahaan Barito Pacific Tbk pada tahun 2016, dan

One-Sample Kolmogorov-Smirnov Test

\begin{tabular}{|c|c|c|}
\hline & & Unstandardized Residual \\
\hline N & & 22 \\
\hline Normal Parameters $\mathrm{a}, \mathrm{b}$ & Mean & OE-7 \\
\hline & Std. Deviation & 1,15635668 \\
\hline & Absolute & 097 \\
\hline Miost Extreme Dimerences & $\begin{array}{l}\text { Positive } \\
\text { Negative }\end{array}$ & $\begin{array}{r}, 086 \\
-, 097\end{array}$ \\
\hline Kolmogorov-Smirnov Z & & ,457 \\
\hline Asymp. Sig. (2-tailed) & & ,985 \\
\hline
\end{tabular}

standar deviasi sebesar Rp.1,711635.

\subsection{Uji Asumsi Klasik}

4.3.1. Uji Normalitas

Uji normalitas bertujuan untuk menguji apakah dalam suatu model regresi linear variabel terikat dan variabel bebas keduanya mempunyai distribusi data normal atau mendekati normal. Untuk mendeteksi normalitas dapat dilakukan dengan uji stastistik yang salah satunya dapat dilihat melalui Kolmogorov- Smirnov (K-S). Hasil yang diperoleh dari uji normalitas adalah sebagai berikut:

Tabel 4.2

Uji Normalitas One Sample Kolmogorov-Smirnov

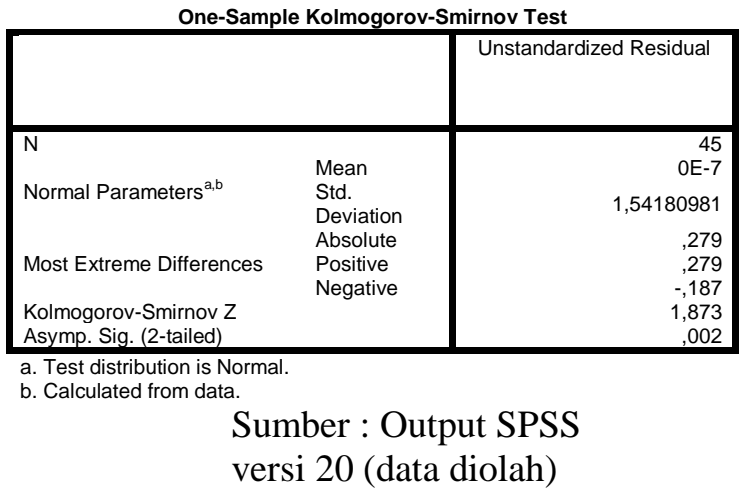

Berdasarkan tabel 4.2 uji normalitas menggunakan uji Kolmorogorov-Smirnov, menunjukan bahwa data tidak berdistribusi secara normal. Karena berdasarkan Output yang dihasilkan nilai Asymp.Sig (2tailed) adalah 0,002, nilai tersebut lebih kecil dari 0,05 atau 5\%. Berikut hasil uji normalitas setelah dilakukan metode semi-log kedalam bentuk logaritma natural.

Tabel 4.3

Uji Normalitas One Sample

Kolmogorov- Smirnov (Setelah Tranformasi Data)

Sumber : Output SPSS versi

20 (data diolah)

Berdasarkan Tabel 4.3 diketahui bahwa setelah ditranformasi data nilai $\mathrm{N}$ dari 45 menjadi 22 dengan nilai signifikan sebesar 0,998. Karena nilai signifikan 0,998 lebih besar dibandingkan tingkat signifikansi 0,05 . Hal ini berarti asumsi normalitas terpenuhi. 
Hasil uji normalitas juga dapat dilihat pada uji normalitas grafik histogram pada gambar 4.1 berikut ini:

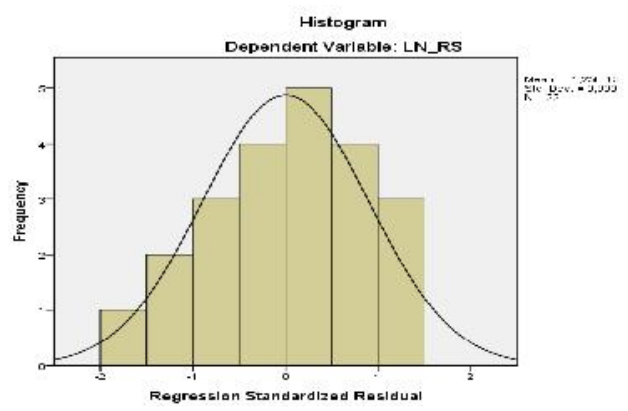

\section{Gambar 4.1}

\section{Grafik Histogram Uji Normalitas}

Grafik histogram pada gambar 4.1 di atas menunjukkan bahwa data berdistribusi normal dengan memiliki kurva berbentuk lonceng dimana distribusi data tidak miring ke kiri maupun miring ke kanan.Hal ini menunjukkan bahwa data telah terdistribusi secara normal.Hal ini juga didukung dengan menggunakan normal P-plot regression.

Hasil uji normalitas juga dapat dilihat pada uji normalitas PPLOT pada gambar 4.2 berikut ini:

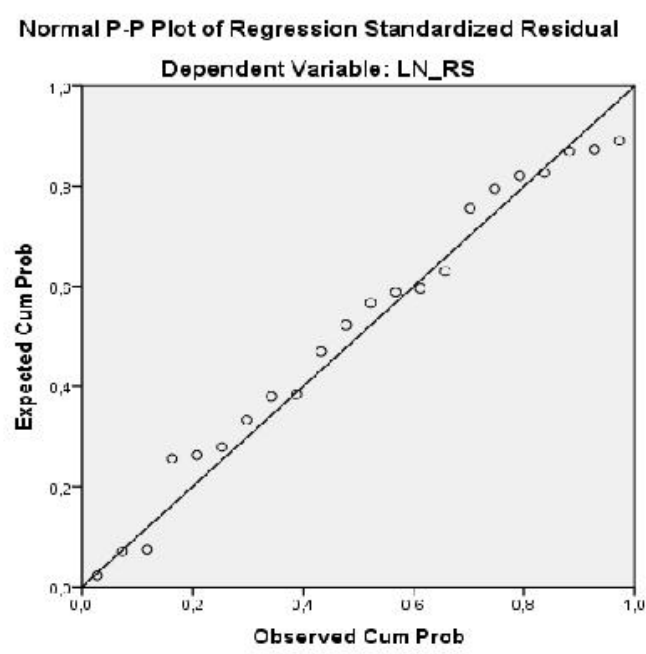

Gambar 4.2 Normal P-Plot Uji Normalitas
Pada dasarnya normalitas sebuah data dapat dikenali atau dideteksi dengan melihat pesebaran data (titik) pada sumbu diagonal dari grafik histrogram dari residualnya. Pada gambar 4.2 diatas menunjukkan data berdistribusi normal karena data menyebar disekitar garis diagonal dan mengikuti arah garis diagonal atau grafik histrogramnya.

\subsubsection{Uji Multikolinearitas}

Dalam suatu model regresi yang baik selain data terdistribusi secara normal juga tidak mengalami multikolinearitas. Multikolinearitas merupakan korelasi antara satu variabel bebas dengan variabel bebas lainnya. Untuk Tabel berikut menyajikan hasil uji multikolinearitas.

Tabel 4.4

Hasil Uji Multikolinearitas

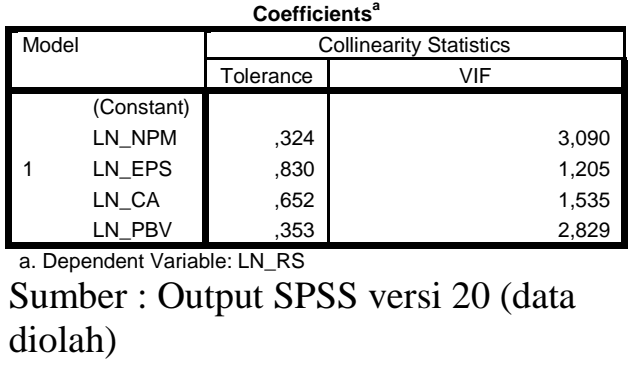

Berdasarkan tabel 4.4 dapat dilihat bahwa nilai VIF setiap variabel dibawah 10 dan nilai tolerance setiap variabel lebih besar dari 0,1 sehingga tidak terdapat hubungan atau korelasi antara satu variabel bebas dengan variabel bebas lainnya. Dari tabel diatas dapat dinyatakan bahwa data penelitian tidak mengalami multikolinearitas sehingga model regresi yang ada 
Jurnal Sains Riset (JSR)

p-ISSN 2088-0952, e-ISSN 2714-531X

http://journal.unigha.ac.id/index.php/JSR

DOI. $10.47647 /$ jsr.v10i12

layak dipakai dalam memprediksi return saham.

\subsubsection{Uji Autokorelasi}

Uji autokorelasi dalam penelitian ini digunakan uji DurbinWatson.Berikut ini hasil berdasarkan uji Durbin-Watson.

\section{Tabel 4.5}

Hasil Uji Autokolerasi (DurbinWatson)

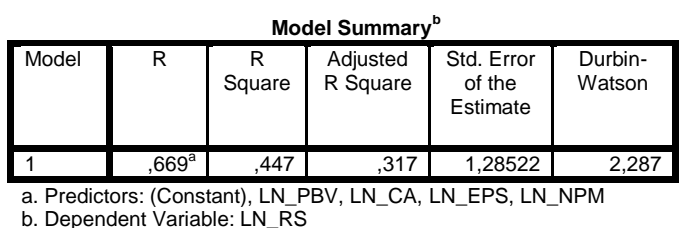

Sumber : Output SPSS versi 20 (data Diolah)

Berdasarkan tabel 4.5 dapat dilihat bahwa nilai DurbinWatson2,197 nilai ini akan dibandingkan dengan nilai tabel Durbin-Watson, lihat pada tabel Durbin-Watson berapa nilai du (batas atas) dengan nilai signifikansi 5\%, jumlah sampel (n) $=22$ dan jumlah variabel independen $(\mathrm{k}=4)$,

$$
\begin{aligned}
\text { DW } & =2,287 \\
\mathrm{dl} & =0,9578 \\
\mathrm{du} & =1.7974 \\
(4-\mathrm{dl}) & =3.0422 \\
(4-\mathrm{du}) & =2.2026
\end{aligned}
$$

Maka dengan begitu dapat hasil perhitungan bahwa nilai DW berada diantara (4-du) dan (4-dl). Maka dalam hasil regresi ini tidak ditolak . (4-du < DW < 4 dl). $(2,1884$ $<2,197<3,0728$ ). Namun jika hipotesisnya nol maka tidak ada korelasi negatif.

\subsubsection{Uji Heteroskedastisitas}

Deteksi ada tidaknya heteroskedastisitas dapat dilakukan dengan melihat ada tidaknya pola tertentu pada grafik scatter plot antara SRESID pada sumbu Y, dan ZPRED pada sumbu $X$. Ghozali
(2013:139) menyatakan Uji Heteroskedastisitas bertujuan menguji apakah dalam model regresi terjadi ketidaksamaan varians dari residual satu pengamatan ke pengamatanyang lain. Jika tidak ada pola yang jelas, serta titik-titik menyebar di atas dan di bawah angka 0 pada sumbu Y, maka tidak terjadi heteroskedastisitas.

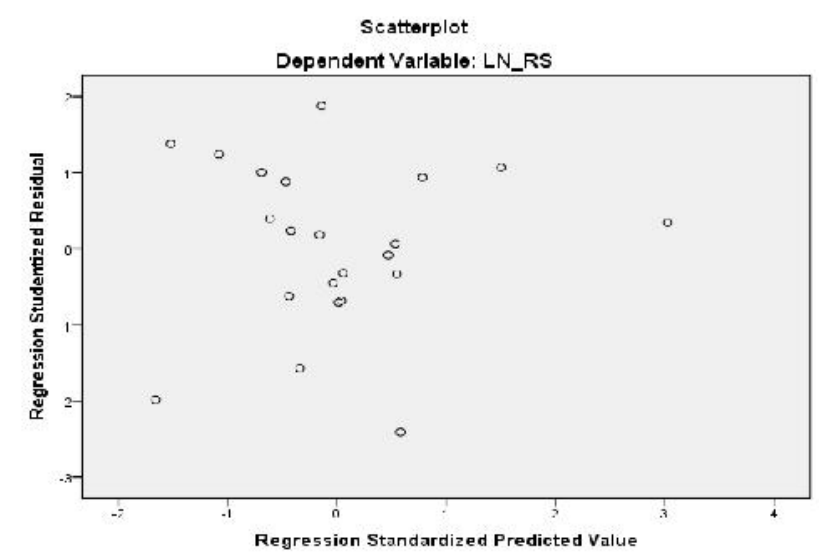

Sumber : Output SPSS versi 20 (data

Diolah)

\section{Gambar 4.3 Uji Heteroskedastisitas}

Perhatikan bahwa berdasarkan Gambar 4.3, tidak terdapat pola yang begitu jelas, serta titik-titik menyebar di atas dan di bawah angka Opada sumbu Y, maka tidak terjadi heteroskedastisitas.

\subsection{Analisis Regresi Linier Berganda}

Penelitian ini dianalisis dengan model regresi linear berganda untuk melihat seberapa besar pengaruh Net Profit Margin (NPM), Earning per share (EPS), Current Asset (CA) dan Price to Book Value (PBV) terhadap returnsaham dengan model dasar sebagai berikut:

$$
\mathrm{LnRS}=\alpha+\beta_{1} \mathrm{NPM}+\beta_{2} \mathrm{EPS}
$$

$+\beta_{3} \mathrm{CA}+\beta_{4} \mathrm{PBV}+\mathrm{e}$

Dimana: 


\section{RS : ReturnSaham \\ $\alpha \quad$ : Konstanta \\ NPM : Net Profit Margin \\ EPS : Earning Per Share \\ CA : Current Asset \\ PBV : Price to Book Value \\ Ln : Log Natural \\ $\beta_{1,2,3,4}$ : Koefesien Regresi \\ e : Error \\ Tabel 4.6}

Analisis Regresi Linier Berganda

\begin{tabular}{|c|c|c|c|c|c|c|}
\hline \multirow{2}{*}{\multicolumn{2}{|c|}{ Model }} & \multicolumn{2}{|c|}{$\begin{array}{l}\text { Unstandardized } \\
\text { Coefficients }\end{array}$} & \multirow{2}{*}{$\begin{array}{c}\text { Standar } \\
\text { dized } \\
\text { Coeffici } \\
\text { ents } \\
\text { Beta }\end{array}$} & \multirow[t]{2}{*}{$\mathrm{t}$} & \multirow[t]{2}{*}{ Sig. } \\
\hline & & B & Std. Error & & & \\
\hline \multirow{5}{*}{1} & (Constant) & $-11,811$ & 3,196 & & $\begin{array}{r}3,69 \\
6\end{array}$ & ,002 \\
\hline & LN_NPM & 1,754 & ,504 & 1,104 & $\begin{array}{r}3,48 \\
3\end{array}$ & ,003 \\
\hline & LN_EPS &,- 111 & ,223 &,- 099 &,- 499 & ,624 \\
\hline & LN_CA &, 501 & , 188 &, 596 & $\begin{array}{r}2,66 \\
7\end{array}$ & ,016 \\
\hline & LN_PBV & $-1,294$ & ,445 &,- 883 & $\begin{array}{r}2,91 \\
2\end{array}$ & , 010 \\
\hline
\end{tabular}

Berdasarkan Tabel 4.5 diperoleh persamaan regresi linear berganda sebagai berikut:

$$
\begin{array}{cr}
\text { LNRS }=-11,811+1,754 \text { NPM- } \\
0,111 \mathrm{EPS}+0,501 \mathrm{CA}- \\
1,294 \mathrm{PBV}+\mathrm{e} &
\end{array}
$$

Keterangan :

1. Persamaan regresi linear berganda diatas, diketahui mempunyai nilai konstanta sebesar -11,811dengan tanda negatif. Sehingga besaran konstanta menunjukkan bahwa jika variabel independen net profit margin (NPM), Earning per share (EPS),Current Asset (CA) dan Price to Book Value (PBV)di anggap konstan, maka variabel dependen yaitu return saham bernilai-11,811.

2. Koefisien variabel NPM sebesar 1,754artinya jika
NPM naik $1 \%$ maka akan meningkatkan return saham sebesar $1,754 \%$ dengan asumsi nilai variabel independen lainnya tetap.

3. Koefisien variabel EPS, sebesar -0,111artinya jika EPSnaik RP.1 maka akan menyebabkan penurunan pada return saham sebesar RP.0,111 dengan asumsi nilai variabel independen lainnya tetap.

4. Koefisien variabel CAsebesar 1,294artinya jika CAnaik RP.1maka akan meningkatkanreturnsahamseb esarRP.1,294 dengan asumsi nilai variabel independen lainnya tetap.

5. Koefisien variabel PBV sebesar -0,544 artinya jika PBV naik RP.1 maka menyebabkan penurunan padareturnsahamsebesarRP.0 ,544 dengan asumsi nilai variabel independen lainnya tetap.

\subsection{Pengujian Hipotesis}

\subsubsection{Pengujian Parsial (Uji t)}

Pengujian ini untuk mengetahui ada atau tidaknya pengaruh satu variabel independen terhadap variabel dependen (secara parsial). Pengujian ini dilakukan dengan membandingkan nilai signifikansi t yang ditunjukkan oleh sig dari $t$ pada Tabel 4.6 dengan tingkat signifikansi yang diambil dalam hal ini 0,05. Jika nilai sig < 0,05 maka variabel independen berpengaruh terhadap variabel dependen. Dari hasil pengujian regresi nilai sig diketahui sebagai berikut : 
Tabel 4.7

Hasil Uji t

\begin{tabular}{|c|c|c|c|c|c|c|}
\hline \multirow{2}{*}{\multicolumn{2}{|c|}{ Model }} & \multicolumn{2}{|c|}{ Coefficients $^{a}$} & & \multirow{3}{*}{ Sig. } \\
\hline & & \multicolumn{2}{|c|}{$\begin{array}{l}\text { Unstandardized } \\
\text { Coefficients }\end{array}$} & \multirow{2}{*}{$\begin{array}{c}\begin{array}{c}\text { Standar } \\
\text { dized } \\
\text { Coeffici } \\
\text { ents }\end{array} \\
\text { Beta }\end{array}$} & \multirow[t]{2}{*}{$\mathrm{t}$} & \\
\hline & & $B$ & Std. Error & & & \\
\hline \multirow{5}{*}{1} & (Constant) & $-11,811$ & 3,196 & & $\begin{array}{r}3,69 \\
6\end{array}$ & ,002 \\
\hline & LN_NPM & 1,754 & ,504 & 1,104 & $\begin{array}{r}3,48 \\
3\end{array}$ & ,003 \\
\hline & LN_EPS &,- 111 & 223 &,- 099 &,- 499 & ,624 \\
\hline & LN_CA &, 501 & 188 & ,596 & $\begin{array}{r}2,66 \\
7\end{array}$ & ,016 \\
\hline & LN_PBV & $-1,294$ & ,445 &,- 883 & $\begin{array}{r}2,91 \\
2\end{array}$ & , 010 \\
\hline
\end{tabular}

Sumber : Output SPSS versi 20 (data Diolah)

\section{Berdasarkan hasil}

perhitungan menggunakan SPSS versi 20, dapat dilihat bahwa variabel independen NPM, CA dan PBV berpengaruh secara signifikan terhadap variabel dependen yaitu return saham dengan tingkat signifikan $(0,003)(0,016)$ dan $(0,010)$ lebih kecil dari 0,05. Sedangkan pada EPS tidakberpengaruh secara signifikan terhadap variabel dependen yaitu return saham dengan tingkat signifikan 0,624 lebih besar dari 0,05 .

1. Hasil Uji Hipotesis pengaruh Net profit margin (NPM) terhadap return saham.

Berdasarkan persamaan regresi terlihat bahwa koefisien untuk variabel ini bernilai positif sebesar 1,754 sehingga dapat diartikan bahwa pengaruh yang diberikan oleh NPM terhadap return saham adalah positif. Koefisien regresi sebesar 1,752 berarti setiap kenaikan NPM sebesar $1 \%$ akan meningkatkan return saham sebesar $1,754 \%$.

Pada hasil pengujian parsial (uji t) terhadap return saham menunjukkan nilai signifikan sebesar 0,003 artinya nilai signifikannya dibawah 0,05 . Sehingga dapat disimpulkan bahwa variabel NPM berpengaruh positif dan signifikan terhadap returnsaham.

2. Hasil Uji Hipotesis pengaruh Earning per share (EPS) terhadap return saham.

Berdasarkan persamaan regresi terlihat bahwa koefisien untuk variabel ini bernilai negatif sebesar-0,111 sehingga dapat diartikan bahwa pengaruh yang diberikan oleh EPS terhadap returnsahamadalah negatif. Koefisien regresi sebesar 0,111 berarti setiap kenaikan EPS sebesar RP.1 akan menyebabkan penurunan terhadap returnsaham sebesarRP.0,111.

Pada hasil pengujian parsial (uji t) terhadap returnsahammenunjukkan nilai signifikan sebesar 0,624 artinya nilai signifikannya diatas 0,05. Sehingga dapat disimpulkan bahwa variabel EPS tidakmempunyai pengaruhsecara signifikan terhadapreturnsaham.

3. Hasil Uji Hipotesis pengaruh Current Asset (CA) terhadap returnsaham.

Berdasarkan persamaan regresi terlihat bahwa koefisien untuk variabel ini bernilai positif sebesar0,501sehingga dapat diartikan bahwa pengaruh yang diberikan oleh CAterhadap

returnsahamadalah positif. Koefisien regresi sebesar 0,501berarti setiap kenaikan 
CAsebesar RP.1 akan meningkatkanreturnsahamseb esar RP.0,458.

Pada hasil pengujian parsial (uji t) terhadap returnsaham. menunjukkan nilai signifikan sebesar 0,016 artinya nilai signifikannya dibawah 0,05 . Sehingga dapat disimpulkan bahwa variabel CAberpengaruh positif dan signifikan

terhadapreturnsaham.

4. Hasil Uji Hipotesis pengaruh Price to Book Value (PBV) terhadap returnsaham.

Berdasarkan persamaan regresi terlihat bahwa koefisien untuk variabel ini bernilai negatif sebesar1,294sehingga dapat diartikan bahwa pengaruh yang diberikan PBVterhadap returnsahamadalah negatif. Koefisien regresi sebesar 1,294berarti setiap kenaikan PBVsebesar

Rp.1akanmenyebabkan penurunan padareturnsaham sebesar Rp.-1,294.

Pada hasil pengujian parsial (uji t) terhadap returnsahammenunjukkan nilai signifikan sebesar 0,010 artinya nilai signifikannya di bawah 0,05. Sehingga dapat disimpulkan bahwa variabel PBVberpengaruh secara negatif dan signifikan terhadapreturnsaham.

\subsubsection{Uji Simultan (Uji F)}

Pengujian ini digunakan untuk menguji signifikansi bagaimanavariabel independen yaitu, net profit margin (NPM), Earning per share (EPS), Current Asset (CA) dan Price to Book Value (PBV) memiliki pengaruhsecara bersamasama terhadap variabel dependen yaitu, returnsaham (RS).

\section{Tabel 4.8}

\section{Hasil uji F}

\begin{tabular}{|c|c|c|c|c|c|c|}
\hline \multicolumn{7}{|c|}{ ANOVA $^{\mathrm{a}}$} \\
\hline Model & & \begin{tabular}{l|l} 
Sum of \\
Squares
\end{tabular} & Df & $\begin{array}{c}\text { Mean } \\
\text { Square }\end{array}$ & $\mathrm{F}$ & Sig. \\
\hline \multirow{3}{*}{1} & Regression & 22,719 & 4 & 5,680 & $\begin{array}{r}3,43 \\
8\end{array}$ & ,031 \\
\hline & Residual & 28,080 & 17 & 1,652 & & \\
\hline & Total & 50,799 & 21 & & & \\
\hline \multicolumn{7}{|c|}{$\begin{array}{l}\text { a. Dependent Variable: LN_RS } \\
\text { b. Predictors: (Constant), LN_PBV, LN_CA, LN_EPS, LN_NPM }\end{array}$} \\
\hline \multicolumn{6}{|c|}{ Sumber : Output SPSS versi 20 (data } & \\
\hline
\end{tabular}

Pada Tabel 4.8 dapat dilihat bahwa hasil uji $\mathrm{F}$ menunjukkan nilai $\mathrm{F}$ hitung sebesar 3,438dengan nilai signifikansi sebesar 0,031. Nilai signifikansi tersebut lebih kecil dari 0,05 hal tersebut menunjukkan bahwa variabel independen berpengaruh secara simultan terhadap variabel dependen. Artinya, setiap perubahan yang terjadi pada Net Profit Margin (NPM), Earning per share (EPS), Current Asset (CA) dan Price to Book Value (PBV) secara bersama-sama berpengaruh secara signifikansi terhadap returnsaham (RS).

\subsubsection{Analisis \\ Determinasi}

Koefisien

Koefisien

determinasi

merupakan suatu nilai (nilai proporsi) yang mengukur seberapa besar kemampuan variabel-variabel bebas yang digunakan dalam persamaan regresi, dalam menerangkan variasi variabel tak bebas. Intinya koefisien determinasi mengukur seberapa jauh kemampuan model dalam variasi variabel dependen. Besarnya koefisien determinasi ini adalah 0 sampai dengan 1. Apabila nilai koefisien determinasi semakin mendekati angka 1, maka semakin baik 
Jurnal Sains Riset (JSR)

p-ISSN 2088-0952, e-ISSN 2714-531X

http://journal.unigha.ac.id/index.php/JSR

DOI. $10.47647 /$ jsr.v10i12

kemampuan model dalam menerangkan variabel dependen. Berikut adalah tabel koefisien determinasi :

\section{Tabel 4.9}

Hasil Uji Koefisien Determinasi $\mathbf{R}^{2}$

\begin{tabular}{|c|c|c|c|c|}
\hline \multicolumn{5}{|c|}{ Model Summary ${ }^{\mathrm{b}}$} \\
\hline Model & $\mathrm{R}$ & $\begin{array}{c}\mathrm{R} \\
\text { Square }\end{array}$ & $\begin{array}{l}\text { Adjusted } \\
\text { R } \\
\text { Square }\end{array}$ & $\begin{array}{l}\text { Std. Error of } \\
\text { the Estimate }\end{array}$ \\
\hline 1 &, $669^{a}$ & ,447 &, 317 & 1,28522 \\
\hline \multicolumn{5}{|c|}{$\begin{array}{l}\text { a. Predictors: (Constant), LN_PBV, LN_CA, LN_EPS, } \\
\text { LN_NPM } \\
\text { b. Dependent Variable: LN_RS }\end{array}$} \\
\hline \multicolumn{5}{|c|}{$\begin{array}{l}\text { Sumber : Output SPSS versi } 20 \text { (data } \\
\text { Diolah) }\end{array}$} \\
\hline
\end{tabular}

Berdasarkan Tabel 4.9 nilai koefisien determinasi terletak pada kolom R-Square. Diketahui nilai koefisien determinasi sebesar 0,669 atau 66,9\%. Angka tersebut menunjukkan bahwa variabel dependen yang digunakan dapat dijelaskan oleh variabel net profit margin (NPM), Earning per share (EPS), Current Asset (CA) dan Price to Book Value (PBV) sedangkan sisanya sebesar $33,1 \%$ dijelaskan oleh faktor-faktor yang lain yang di anggap tetap yang tidak dimasukkan ke dalam penelitian ini.

\subsection{Pembahasan}

4.6.1. Pengaruh Net profit margin (NPM) Terhadap ReturnSaham(RS)

Berdasarkan persamaan regresi terlihat bahwa koefisien untuk variabel ini bernilai positif sebesar 1,754 sehingga dapat diartikan bahwa pengaruh yang diberikan oleh NPM terhadap return saham adalah positif. Dengan nilai signifikan sebesar 0,003 artinya nilai signifikannya dibawah 0,05 . Sehingga dapat disimpulkan bahwa variabel NPMberpengaruh positif dan signifikan terhadapreturn saham.
Hal ini menunjukkan bahwa perusahaan yang mendapatkan NPM yang lebih besar konsisten memiliki returnsaham yang lebih besar. Perusahaan dengan kemampuan menghasilkan pendapatan bersihnya terhadap penjualan yang di capai mempengaruhi investor untuk masuksehingga sahamnya di pasar bursa banyak diburu pembeli. Peningkatan permintaan terhadap saham dapat mempengaruhi harga saham tersebut, sehingga hal ini berdampak terhadap returnsaham.

Hasil ini didukung oleh penelitian sebelumnya yang dilakukan oleh Putra(2015) bahwa Secara simultan bahwa ROA, NPM, dan EPS berpengaruh terhadap returnsaham. Secara parsial ROA dan NPM berpengaruh positif dan signifikan terhadap returnsaham, sedangkan EPS memiliki pengaruh secara negatif dan tidak sigfnifikan terhadap returnsaham.Namun bertolak belakang dengan penelitian yang dilakukan oleh Wasih (2017) yang menyatakan bahwa returnon asset, net profit margin, price earning ratio, price to book value, dan debt to equity ratio secara bersama-sama berpengaruh terhadap returnsaham. Namun NPM tidak berpengaruh terhadap returnsaham.sedangkan PBV berpengaruh terhadap returnsaham.

\subsubsection{Pengaruh Earning Per Share (EPS) Terhadap ReturnSaham (RS)}

Berdasarkan persamaan regresi terlihat bahwa koefisien untuk variabel ini bernilai negatif sebesar -0,111 sehingga dapat diartikan bahwa pengaruh yang diberikan oleh EPS terhadap return saham adalah negatif. Dengan nilai signifikan sebesar 0,624 artinya nilai signifikannya diatas 0,05 . Sehingga 
dapat disimpulkan bahwa variabel EPS tidakmempunyai pengaruh secara signifikan terhadapreturn saham.

Hal ini mengidentifikasikan bahwa sebagian besar investor menginginkan laba jangka pendek berupa capital gaindari investasinya sehingga mempertimbangkan pembelian saham tanpa melihat EPS. Hasil ini didukung oleh penelitian sebelumnya yang dilakukan oleh Putra(2015) bahwa secara simultan bahwa ROA, NPM, dan EPS berpengaruh terhadap returnsaham. Secara parsial ROA dan NPM berpengaruh positif dan signifikan terhadap returnsaham, sedangkan EPS memiliki pengaruh secara negatif dan tidak sigfnifikan terhadap returnsaham. Namun penelitian ini bertolak belakang dengan penelitian yang dilakukan oleh Yusril (2015) yang menyatakan bahwa secara simultan dan signifikan ROA, EPS dan DER berpengaruh terhadap return saham. Variabel ROA dan EPS berpengaruh singnifikan terhadap return saham namun DER tidak berpengaruh signifikan terhadap return saham.

\subsubsection{Pengaruh Current Asset} (CA) Terhadap

\section{ReturnSaham (RS)}

Berdasarkan persamaan

regresi terlihat bahwa koefisien untuk variabel inibernilai positif sebesar 0,501 sehingga dapat diartikan bahwa pengaruh yang diberikan oleh CA terhadap return saham adalah positif. Dengan nilai signifikan sebesar 0,016 artinya nilai signifikannya dibawah 0,05. Sehingga dapat disimpulkan bahwa variabel CA berpengaruh positif dan signifikan terhadapreturn saham.

Dalam mengoperasikan sebuah perusahaan tingkat current asset (CA) sangat dilihat karena perputaran yang tinggi dan paling cepat bisa dijadikan uang tunai sehingga para menarik para investor untuk membeli saham dengan begitu pada harga saham akan mempengaruhi return saham dan para investor juga sangat tertarik pada investasi jangka pendek. Ini sesuai dengan teori yang dikemukakan oleh (Fahmi, 2018:31) Current Asset merupakan aset yang memiliki tinggkat perputaran yang tinggi dan paling cepat bisa dijadikan uang tunai, dengan penetapan periode waktu biasanya 1 tahun.

\subsubsection{Pengaruh Price to Book Value (PBV) Terhadap ReturnSaham (RS)}

Berdasarkan persamaan regresi terlihat bahwa koefisien untuk variabel ini bernilai negatif sebesar 1,294 sehingga dapat diartikan bahwa pengaruh yang diberikan PBV terhadap return saham adalah negatif. Dengan signifikan sebesar 0,010 artinya nilai signifikannya di bawah 0,05. Sehingga dapat disimpulkan bahwa variabel PBVberpengaruh secara negatif dan signifikan terhadapreturn saham.

Apabila PBV rendah maka return yang akan diterima akan meningkat, disebabkan PBV yang rendah menunjukkan bahwa harga sahamnya murah, jika harga saham berada dibawah nilai bukunya, ada kemungkinan harga saham tersebut menuju keseimbangan minimal sama dengan nilai bukunya dan harga saham perusahaan tersebut berpotensi lebih besar untuk naik dan return yang diterima akan meningkat.

Hasil ini didukung oleh penelitian sebelumnya yang dilakukan oleh Wasih (2017) yang menyatakan bahwa returnon asset, 
net profit margin, price earning ratio, price to book value, dan debt to equity ratio secara bersama-sama berpengaruh terhadap returnsaham. Namun NPM tidak berpengaruh terhadap returnsaham. Sedangkan PBV berpengaruh terhadap returnsaham.

\subsubsection{Variabel Yang Paling Dominan Berpengaruh Terhadap Return Saham \\ Dalam penelitian ini yang} menjadi variabel paling dominan yang mempengaruhi return saham adalah Net Profit Margin (NPM) karena dalam penelitian ini hanya variabel yang mempengaruhi return saham yaitu NPM, CA, dan PBV. Berdasarkan persamaan regresi terlihat bahwa koefisien untuk variabel ini NPM bernilai positif sebesar 1,754 sehingga dapat diartikan bahwa pengaruh yang diberikan oleh NPM terhadap returnsaham adalah positif, sedangkan nilai signifikan sebesar 0,003 artinya nilai signifikannya dibawah 0,05. Sehingga dapat disimpulkan bahwa variabel NPMberpengaruh positif dan signifikan terhadapreturnsaham.

$$
\text { Berdasarkan persamaan }
$$

regresi terlihat bahwa koefisien untuk variabel CA bernilai positif sebesar 0,501 sehingga dapat diartikan bahwa pengaruh yang diberikan oleh CA terhadap returnsaham adalah positif,sedangkan nilai signifikan sebesar 0,016 artinya nilai signifikannya dibawah 0,05 . Sehingga dapat disimpulkan bahwa variabel CA berpengaruh positif dan signifikan terhadapreturnsaham. Sedangkan berdasarkan persamaan regresi terlihat bahwa koefisien untuk variabel PBV bernilai negati sebesar -1,294 sehingga dapat diartikan bahwa pengaruh yang diberikan oleh PBVterhadap return saham adalah negatif,sedangkan nilai signifikan sebesar 0,010 artinya nilai signifikannya dibawah 0,05. Sehingga dapat disimpulkan bahwa variabel PBV berpengaruh secaranegatif dan signifikan terhadapreturn saham.

Dari kesimpulan diatas dapat disimpulkan bahwa NPM memiliki nilai koefesien tinggi yaitu 1,754 dengan nilai signifikan paling terkecil yaitu 0,003 . Karena variabel yang paling dominan adalah variabel dengan koefesien tertinggi dan tingkat nilai signifikannya paling terkecil.

\section{KESIMPULAN DAN SARAN}

\subsection{Kesimpulan}

Hasil penelitian pada perusahaan Manufaktur dengan sub sektor kimia yang terdaftar di Bursa Efek Indonesia (BEI), berdasarkan data yang di ambil dari tahun 2014 sampai dengan 2018 dapat disimpulkan sebagai berikut :

5. Hasil Uji Hipotesis pengaruh Net profit margin (NPM) terhadap return saham.

Berdasarkan persamaan regresi terlihat bahwa koefisien untuk variabel ini bernilai positif sebesar 1,754. Koefisien regresi sebesar 1,752 berarti setiap kenaikan NPM sebesar $1 \%$ akan meningkatkan return saham sebesar 1,754\%.Pada hasil pengujian parsial (uji t) terhadap return saham menunjukkan nilai signifikan sebesar 0,003 artinya nilai signifikannya dibawah 0,05 . Sehingga dapat disimpulkan 


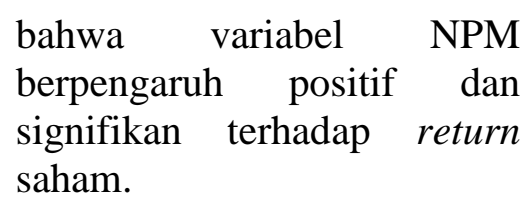

6. Hasil Uji Hipotesis pengaruh Earning per share (EPS) terhadap return saham.

Berdasarkan persamaan regresi terlihat bahwa koefisien untuk variabel ini bernilai negatif sebesar 0,111. Koefisien regresi sebesar -0,111 berarti setiap kenaikan EPS sebesar RP.1 akan menyebabkan penurunan terhadap return saham sebesar RP.0,111. Pada hasil pengujian parsial (uji t) terhadap return saham menunjukkan nilai signifikan sebesar 0,624 artinya nilai signifikannya diatas 0,05 . Sehingga dapat disimpulkan bahwa variabel EPS tidak mempunyai pengaruh secara signifikan terhadap return saham.

7. Hasil Uji Hipotesis pengaruh Current Asset (CA) terhadap return saham.

Berdasarkan persamaan regresi terlihat bahwa koefisien untuk variabel ini bernilai positif sebesar 0,501. Koefisien regresi sebesar 0,501 berarti setiap kenaikan CA sebesar RP.1 akan meningkatkan return saham sebesar RP.0,458. Pada hasil pengujian parsial (uji t) terhadap return saham. menunjukkan nilai signifikan sebesar 0,016 artinya nilai signifikannya dibawah 0,05 . Sehingga dapat disimpulkan bahwa variabel CA berpengaruh positif dan signifikan terhadap return saham.

8. Hasil Uji Hipotesis pengaruh Price to Book Value (PBV) terhadap return saham.

Berdasarkan persamaan regresi terlihat bahwa koefisien untuk variabel ini bernilai negatif sebesar 1,294. Koefisien regresi sebesar -1,294 berarti setiap kenaikan PBV sebesar Rp.1 akan menyebabkan penurunan pada return saham sebesar Rp.-1,294. Pada hasil pengujian parsial (uji t) terhadap return saham menunjukkan nilai signifikan sebesar 0,010 artinya nilai signifikannya di bawah 0,05 . Sehingga dapat disimpulkan bahwa variabel PBV berpengaruh secara negatif dan signifikan terhadap return saham.

9. Variabel Yang Paling Dominan Berpengaruh Terhadap Return Saham

Dalam penelitian ini yang menjadi variabel paling dominan yang mempengaruhi return saham adalah Net Profit Margin (NPM) karena NPM memiliki nilai koefesien tinggi yaitu 1,754 dengan nilai signifikan paling terkecil yaitu 0,003. Karena variabel yang paling dominan adalah variabel dengan koefesien tertinggi dan tingkat nilai signifikannya paling terkecil.

\subsection{Keterbatasan Penelitian}

Namun dalam penelitian ini peneliti juga memiliki keterbatasan yaitu: 
1. Sampel penelitian terbatas pada Perusahaan Manufaktur sub sektor kimia yang terdaftar di di Bursa Efek Indonesia, perusahaan Manufaktur banyak terbagi lagi dalam beberapa sektor dan di dalam sektor terdiri beberapa sub sektor, sehingga hasil penelitian belum dapat di generalisasi. Dari sampel tersebut tidak dapat menggambarkan secara umum semua jenis perusahaan di Indonesia.

2. Peneliti hanya menggunakan 4 variabel (Net Profit Margin (NPM), Earning per share (EPS), Current Asset (CA) dan Price to Book Value $(\mathrm{PBV})$ ) dalam menganalisa perusahaan Manufaktur sub sektor kimia terhadap mempengaruhi return saham sehingga masih banyak variabel-variabel lain yang belum diteliti.

\subsection{Saran}

Berdasarkan hasil analisis penelitian dan keterbatasan penelitian, maka peneliti dapat memberikan beberapa saran, antara lain :

1. Dalam penelitian selanjutnya disarankan tidak hanya menggunakan perusahaan manufaktur saja sebagai sampel tetapi juga menggunakan seluruh perusahaan yang terdaftar di Bursa Efek Indonesia.

2. Memperluas sampel penelitian misalnya memperpanjang periode pengamatan dan menambahkan sampel perusahaan dari semua jenis kategori industri di pasar modal yang lain misalnya di Bursa Efek Malaysia atau Bursa Efek Singapura agar sampel yang di dapat lebih akurat.

3. Untuk penelitian selanjutnya variabel independen yang tidak berpengaruh di ganti dengan variabel lain, seperti curret ratio, total asset turnover, debt to equity ratio, return on equity dan sebagainya.

\section{DAFTAR PUSTAKA}

Abdullah, Achmad Ridwan. 2011. Perlakuan Akuntansi Aset Biologis PT Perkebunan Nusantara XIV Makassar (Persero). Makassar: Universitas Hasanuddin.

Aryanti. 2016. Pengaruh ROA, ROE, NPM, dan CR Terhadap Return Saham Pada Perusahaan Yang Terdaftar Di Jakarta Islamic Index (JJI). Jurnal I-Finance Vol.2. No.2.

Darmadji, Tjiptono dan Fakhruddin. 2012. Pasar Modal Indonesia. Edisi ke-3. Jakarta: Salemba Empat.

Fahmi, Irham. 2018. Analisis Laporan Keuangan. Bandung: Cetakan ke-6. Alfabeta.

Hanafi, Mamduh M \& Abdul Halim, 2018. Analisis Laporan Keuangan. Cetakan ke-2, Edisi ke-5.Yogyakarta: UUP STIM YKPN. 
Jurnal Sains Riset (JSR)

p-ISSN 2088-0952, e-ISSN 2714-531X

http://journal.unigha.ac.id/index.php/JSR

DOI. $10.47647 /$ jsr.v10i12

Hery. 2015. Analisa Laporan Keuangan. Edisi ke 1. Yogyakarta: Center For Academic publishing service.

Hery. 2016. Analisis Laporan Keuangan. Jakarta: Grasindo

Hermuningsih, Sri. 2012. Pengantar Modal Indonesia.

Yogyakarta: UPP STIM YKPN

Jogiyanto, H.M. 2010. Teori Portofolio dan Analisis Investasi. Edisi ke-7. BPFE. Yogyakarta.

Jumingan. 2011. Analisis laporan keuangan. Jakarta: Buni Aksara.

Harmono. 2014. Manajemen Keuangan.Jakarta: Bumi Aksara.

Kasmir. 2015. Analisis laporan keuangan. Cetakan ke-7. Jakarta: Raja Grafindo Persada.

Latumaerissa, Julius R. 2013. Bank Dan Lembaga Keuangan Lain. Jakarta: Salemba Empat..

Munawir. 2014. Analisis laporan keuangan. Yogyakarta: Liberty,
Putra, Dianata Eka .2013. Berburu Uang Dipasar Modal. Semarang: Efthar.

Putra, Ferdinan Eka.. 2015. Pengaruh ROA, NPM, dan EPS Terhadap Return Saham Pada Perusahaan Makanan dan Minuman Yang Terdaftar Di Bursa Efek Indonesia Periode 2010-2014. Jurnal EMBA, Volume 4 Nomor 4.

Soemitra, Andri. 2014. Masa Depan Pasar Modal Syariah di Indonesia. Jakarta: Kencana.

Wasih, Nela Mirda 2017. Pengaruh Return On Asset, Net Profit Margin, Price Earning Ratio, Price To Book Value, Dan Debt To Equity Ratio Terhadap Return Saham Pada Perusahaan Manufaktur Yang Terdaftar Di BEI Periode 2014-2016. Jurnal Fakultas Ekonomi Universitas Maritim Raja Ali Haji Tanjungpinang, Kepulauan Riau.

Yusril. 2015. Pengaruh Return On Asset, Earning Per Share, Dan Debt To Equity Ratio Terhadap Return Saham Sektor Industri Dasar dan Kimia Yang Terdaftar Di BEI. Jurnal Ekonomi, Volume 20 Nomor 1. 